\title{
A Welcome Antidote to the Evangelism of Compulsory Optimism and Resilience
}

\author{
Tony Carton \\ Wellington Institute of Technology, Wellington, New Zealand \\ Email: tony.carton@weltec.ac.nz
}

How to cite this paper: Carton, T. (2017). A Welcome Antidote to the Evangelism of Compulsory Optimism and Resilience. $A d$ vances in Applied Sociology, 7, 83-94. https://doi.org/10.4236/aasoci.2017.72005

Received: January 14, 2017

Accepted: February 25, 2017

Published: February 28, 2017

Copyright (C) 2017 by author and Scientific Research Publishing Inc. This work is licensed under the Creative Commons Attribution International License (CC BY 4.0).

http://creativecommons.org/licenses/by/4.0/

\begin{abstract}
This article problematizes the current western hubris around resilience and compulsory positivity that has ideologically insinuated itself into the addiction counselling treatment field. It argues that these discourses emanate less from clinical propositions but represent a virulent enactment of a neo-liberal agenda wherein language is implicated in the recreation of new subjectivities conducive to a declining social state. We also apprehend the ideological effect of verbal softeners, euphemisms and fabricated binaries and inversions routinely utilized by addiction clinicians enrolled as ground troops in this project. We also anticipate some likely challenges to this. The objective of this article is to reinstall the veracity of vulnerability and deficit appreciation, thus problematizing a prevailing Pollyanna version of resilience. It reviews the ineluctable alienating trajectory of lexicons used in the field over a few decades in various interventions, including Twelve Step Therapy, Client Centred Practice, Cognitive Behavioural Practice and Motivational Interviewing in order to show how clinicians now reproduce neo-liberal subjectivity through a language that constitutes subjectivity amenable to a declining social state. We apprehend grammatical structures that stigmatise sickness to reproduce hegemony of compulsory wellness.
\end{abstract}

When self-esteem, or others' adulation,

Would cunningly persuade us we are something,

Above the common level of our kind,

The grave gainsays the smooth complexioned-flattery,

And with blunt truth acquaints us with what we are-The Grave by Robert Blair (Clymer, 1995)

Of the argument with others we make rhetoric,

Of the argument with ourselves we make poetry-W. B. Yeats (Bloom, 1970) 


\section{Keywords}

Resilience, Deficit, Addiction, Twelve Step Therapy, Client Centred Practice, Cognitive Behavioural Practice, Motivational Interviewing

\section{Introduction}

For numerous reasons, a cursory review at the changing texture of counsellor/client interaction in the addiction field provides a fruitful area to illustrate tectonic shifts in the declining social state in the western world. To some degree, practices in the substance abuse field provide an exemplar of a field, less contaminated and gentrified by the rigours of professionalism nor by the elitism of academia (Simard-Gagnon, 2016). As such many practioners have recourse to various vocabularies relegated in the mainstream. Much to the annoyance of the professionalization processes and the disgust of academia the average addiction worker utilizes mainstream psychological rational vocabularies often as a worthy supplement to the affective and traditional knowledges often marginalised by the hidden curriculum of professionalism. Psychological addiction theory sometimes serves as a clearing house to further the needs of the psy-sciences yet more currently the prerequisites of the market. Addiction workers often have a past affinity with mood altering substances and sophistication in managing the mood swings of the addiction field, be it the depressant effect of an evidence based practice compulsion or currently the euphoria of the prevailing superficial rhetoric around resilience. However, they are well acquainted with the "blunt truth" Gray (Clymer, 1995: p. 135) of suffering such as withdrawal, overdose or the metaphysics of powerlessness and desperation which they recognise as precursors to resilience. Moreover like any process addiction, a zealous reliance on the resilience discourse may result in dangerous "side effects" (Davis, 2016: p. 135).

\section{Tragedy}

No one would continue to read a novel that began with the central character enjoying a nice cup of tea with Aunt Margaret, a woman of meticulous virtue, unless that is, the author hinted that during the conversation there was a growing awareness of her secret little vice ... Notably that she was perhaps a serial killer. Indeed, this could explain the writer's earlier comment that the tea seemed to have a strange taste. Now the idea of a kind aunt murdering her nephew and his wholesome new bride-to-be is repellent, but maybe not as much so as reading four volumes of unconstrained wholesomeness. There would be all the moral difference of stopping reading at page 3 rather than 323 .

We see in this piece a potential horror due to a collision of matrices (Koestler, 1964). The binary of a kind respectable aunt and her secret life as a serial killer provides a compelling narrative of tension and resolution. Whether we admit to it or not we are deeply attracted to tragedy. It is probably fair to say that most compelling is the tension rather than the resolution and one that is not bought 
cheaply.

William Blake also knew the importance of tragic empiricism.

Wisdom is sold in the desolate market where no one comes to buy or in the withered field, where the farmer ploughs for bread in vain.

Blake \& Stevenson (2007)

\section{The Addiction Field: An Introduction}

Addiction has been positioned as a moral failing, a genetic predisposition, a repressed subjectivity or a failure to learn, but no one can deny it is a thoroughly human failing. However in the words of Yeats, this has "utterly changed" (Bloom, 1970), not so much maybe to a terrible beauty but a highly insipid and banal beauty. The counsellor/client clinician interaction now plumbs the dizzying depths of a customer/sales person transaction. The patient is no longer powerless but empowered, now a customer and a rational agent exercising free choice "participating in their own oppression" (Aquash, 2013). Today rather than buying shoes or spaghetti they are buying recovery from addiction. Historically the drama was rendered prosaic by the medical model, sinful by the moral model yet now it is rendered with the exaltation of a business opportunity. Yet for many the recovery from addiction is a holy thing often involving an involuntary visit to the Garden of Gethsemane for the chronic unbeliever. But somehow AoD workers evolve a sophisticated default in getting on with the business of this "dalliance with an alien thing" (Bloom, 1970), namely an intoxicated neoliberalism, named as resilience.

\section{Resilience and Practices of Excellence}

The difficulty is that these fiercely democratic templates of resilience, positivity and hyper-esteem propel a stunning paradox that we are forced by our own free choice to accept. And counsellors skilfully force this free choice on unsuspecting clients, who freely accept them. This decentring of client, counsellor and organisations is an alienating process facilitated by counsellors who have become the ground troops of these ideological templates, increasingly and willingly acting to subjugate vocabularies of morality and pain as they empower innocent clients to police themselves into the dizzying heights of compulsory optimism.

\section{Literature}

Similar to other addictions to legal drugs and processes the neo-liberal rhetoric is pervasive and "there appears to be no area of social or 'psy' science inquiry that cannot be recoded in terms of resilience" (Davis, 2016: p. 136).

In an era of hallowed secularity, it feels sinful to critique resilience and high self-esteem. Such things are unequivocally good, disabled morally and culturally from problematizing. Moreover, it is tricky to critique the Janus face and the dialectical tenor of these, however recently authors have garnered (albeit belatedly) the audacity to critique it. Interestingly mobilising the arts of humour, notably sarcasm, Davis (2016: p. 136) writes "Reslience catches not only salaried killers 
but also psychotherapists, nurses, midwives and social workers in its net". $\mathrm{He}$ also refers to it being more termite like than lion like. There is a delicious dignity in resisting the almighty lion but not so in resisting the neo-liberal stealth of the termite.

DeVerteui \& Golubchikov (2016) paraphrased the heavily secular philosopher Dennett's contention that when we critique a concept we need also in the first instance to give it appropriate respect. (Dennet does not seem to follow his own advice here when it comes to his own critique of religion, but this is a current form of sophisticated common sense). This is appealing logically, maybe even morally; however, there are opportunities in approaching a concept with a sacred disrespect as tragedy is often the mirror image of farce. The writers talk about a "de-neo-liberalisation" (p. 143) of the concept and they urge redemption (through suffering or a least irritation) of the concept of resilience.

Davis (2016) describes the termite like existence of both resilience and neo-liberalism and its intrusive effect on "empathic interdiscurvity (p. 135)". He urges a co-option of the term. However, AoD workers often source a black humour as a means of ridiculing fashionable intrusions and are accomplished hijackers of the concept. Moreover, they are also well aware of the nature of interdiscursivity on all counselling practice. They also know the professional sanctions involved in critiquing the latest designer concepts and underground tactics are often the best response.

Continuing the termite metaphor, he writes "Neo-liberalism governs as sophisticated common sense, a reality principle remaking institutions and human beings everywhere it settles, nestles, and gains affirmation" (p. 136). It may be that the utilization of farce presents an appropriate means to address the colonising stealth of the resilience discourse and its dialectical effect. The sophisticated nonsense around resilience and neo-liberalism more and more tastes like a beer going flat. He also describes the difficult of critiquing the dialectical. "Resilience discourse is both a symptom of neo-liberalism's creeping progress" (135) that serves to retard any social justice progress.

Wright (2012: p. 279) describes the tragedy involved in this sophistry when "seemingly incompatible goals of social justice and fairness are being collapsed upon and subsumed by market logics" (p. 279).

Simard-Gagnon (2016: p. 220) comments on how "upholding resilience as an ideal in the face of adversity individualizes hardships and adds to the strain of struggling individuals, and calls for academics to articulate a more subversive means of resistance" (p. 220).

She makes a very potent and worthwhile strategic conflation between liberalism and neo-liberalism which goes possibly to explain the termite behaviour of both neo-liberalism and the resilience discourse. This liberal-cum-neoliberal conflation is also referred to in Wright p. 281 where he cites Codd et al. "liberal critiques of state saw it as enforcer of negative rights (freedom from interventions), neo-liberal as facilitator of market logics".

They nicely address the cliff edge nature of high esteem and resilience and 
address how the concepts act to make things worse. The history of the resilience has moved from an ecological natural understanding (Hutcheon \& Lashewicz, 2014: p. 1384) origin to an individualising human failing. The conflation between natural disasters and human failing is of course not a new strategy, inviting multiple discourses and inter-textualities of nature, spiritualty and racism, an instance being the Irish famine when God apparently intervened through the doctrine of providentialism, precursor to neo-liberalism to rid the British colony of an idle peasantry in favour of an idle landlord class. Or in an updated version treating "social phenomena like the credit crunch and recession as if they were natural disasters" (Joseph cited in Davis p. 135).

DeVerteuil \& Golubchikov, (2016) refer to a useful and appropriate concept for the addiction field, referring to a conflation between evolutionary resilience and equilibrium resilience which amounts to fatalism (White and O'Hare cited in DeVerteuil \& Golubchikov, 2016). This goes to the heart of homeostasis in the addiction physiological and systemic cycles that describe the effect of tolerance. Addiction and other health clinicians have developed a tolerance to the nonsense of the resilience and excellence discourses and possess refined and sophisticated modes of passivity.

However Sokolon (2013) refreshingly addresses the role of shame and how Aristotle addressing resilience to the taboo negative concept of shame and "locates this potential for ethical assessment in friendship and not in public discourse" (p. 447) moving it away the end points of an individual emotion or mundane conventional public norms to a mid-point where he makes shame indispensable for moral progress.

Aristotle called for "a reflective practice that nurtures practical wisdom and questions 'why' before 'how'” (Blockley, 2015: p. 18) involving many values (some in "wicked" conflict).

\section{Methodology}

By being resilient we are expected to meet "Structural pressure, including oppression ... with individual elasticity, rebounding and adaptation" (Bracke, 2016: p. 851).

Textual and discourse analysis is a valuable method for numerous reasons. The tool of the trade in counselling is the use of language. Freud evolved the idea of talk therapy. This was consistent with a long-standing religious idea from John "the truth sell set you free" (Zizek, 2011). Practices in the addiction field have often been based on this confessional premise through steps 6 and 7 (Alcoholics Anonymous, 2001) around a cathartic release that frees the soul, or in secular psychodynamic terminology subjectivity. This was accomplished through the use of language often construed as a linear device of transmittal. However, discourse analysis recognises the transitory ethereal yet constitutive tenor of language which often deserts the cold comfort of evidence base in order to create and sustain systems of reality. Importantly critical discourse analysis recognises the political and power effects of these definitions of reality. 
Texts are produced, consumed and interpreted. They are constituted and in turn constitute social reality in a dialectic relationship with other practices. Crucially implicated is the issue of power and "any detailed analysis of power in interaction needs to be informed by an account of context, the social relationships it sets up between participants, and speakers' rights and obligations in relation to their discursive and institutional roles and identities" Thornborrow (2002: p. 3435). The context in the twelve-step movement was a peer institutional yet vehemently self-supporting framework.

Texts can also be used strategically to invert previous social realities when colliding discourses meet. This often provides an illusion of logical argument. However, there is an asymmetry wherein older discourses are marginalised through the use of caricature and new ones constructed with an aura of innovation and progress. Teaching and learning materials are thus constructed on this basis (Carton, 2014).

\subsection{Individual Aetiology yet a Collective Intervention-Twelve Steps Therapy}

The twelve-step movement provided an inter-subjective domain utilizing prevailing, dominant but also subjugated discourses, no doubt some in (Blockley, 2015: p. 18) such as an anarchic-communistic peer democratic and empirical milieu and the dominant medical and moral models. It engaged with religion, crucially in its performative rather than creedal sense, though it appended the verbal softener spiritual (a word that has descended to currently meaning nothing, albeit a middle class chronically inoffensive nothing).

Therapy was virulently peer based, and included an honest and forthright recognition of personal character defects and the Aristotelian recourse to the concept of shame (Sokolon, 2013). A twelve-step meeting was a site where individuals created and sustained meaning, similar to a church, mosque or temple. The entrance obligations were verbalised in a supremely negative, minimalist and tentative manner "the only requirement for membership is a desire to stop drinking", (Alcoholics Anonymous, 2001) Twelve step ideologies, much to the annoyance of modernist dominant dispositional and medical models, embraced a paradox in that although the aetiology of addiction was individual (a genetic or spiritual deficit) the intervention was collective.

In the scroll of the twelve steps, the most common word was we. Often recovery was accomplished by the recital of personal stories that revisited tragedies. The issue of shame in its Aristotelian sense (Sokolon, 2013) was addressed in a room of friends.

\subsection{From We to I-Client Centred Practice}

The desertion of the collective to personal pronoun yielded constructive and paradoxical effects. It created the conditions of possibility of a sophisticated avoidance of collective responsibility by using the word $I$. Critical discourse analysis provides a link between wider societal structures and rhetorical micro-prac- 
tices. In the liberal west collective entities such as churches, trade unions even the military to some extent were collapsing. If a soldier going into battle was to say $I$ don't want to go, or a striking miner was to say $I$ don't want to strike they would be treated with disrespect, the idolatry of the selfmarginalised by the imperative of solidarity. The concept of the self has now become the default position and the resting place of the conscience in the liberal west.

Client centred practice focused very much on the I. However, much of the therapy involved a necessary revisit to the area of first emotional deregulation. In fact, an avoidance of this was sanctioned against by terms such as denial. This concept included the presumption that resilience was not a fixed natural or biological entity but was gained by the revisiting of old traumas. The practice was anything but strength based, involving as it did on a focus on past hurts, shame and loss. Therapy was carried out by a guru like person able to understand the vast abstractions of the psyche. It was envisaged as long term, and often provided in government funded rehabilitation centres. The practice was very much based on a vehement assertion of non-judge-mentalism. The counsellor eschewed the giving of advice but merely reflected, paraphrased and gave minimal encouragers and asked open ended questions in order to elicit a response.

However invisible it was the counsellor did have institutional, academic or professional power. Rather than the mythology of two peer individuals having an equal and honest discussion the power relationship was not made explicit. Paradoxically it is in the unsaid that power is enacted as the "opacity of these relationships between discourse and society is itself a factor securing power and hegemony" (Fairclough 1995: p. 132).

\subsection{From Should to Need-Cognitive Behavioural}

As CCP abandoned the collective, CBT eventually deserted any semblance of morality almost to the point of protesting too much (Dean, 2008). Unless they relish the thought of an early exit to their career, counsellors avoid the word should. Ellis (1992) addressed the overuse of the term should referring to self-judgment under the category "musterbation".

Whether we admit it or not counselling as an interaction is based on linearity with predictive results that intrinsically involves power.

The rules of two-party conversations are cited (Sacks, 1974).

1) If one person asks a question, the other answers it,

2) The person who asks the questions can talk again after the other answers and can ask questions.

The order of discussion and conversation markers combines to enforce a power network.

Proponents of Cognitive Behavioural Practice were more honest in acknowledging a power difference. The role of the therapist was more of a teacher, thereby possessing superior knowledge. Unlike CCP the duration was finite; the goal was to enable the client to become their own counsellor. Again, the citation of deficit was revisited, this time in the shape of irrational thinking learned in the past. 
Once again, a solution was garnered by embracing the negative as a precursor to resilience.

The move from should to need gives the impression of a binary opposition and also it signals a profound change in the counsellor/clinician interaction in that it acts to effectively disappear resistance, while presenting the ideal reason to resist. When we are presented with should we can disagree, presented with cold logic around needs it feels sacrilegious. There is a subversive dignity in resisting the controlling parent who says you shouldn't, however the prosaic in an equal relationship who reminds you of your unwanted needs provides an interaction of blind logic where resistance is dissipated.

Counsellors have become inebriated by a chronic humanism and a commitment to a misunderstood Hegelian dialectical idealism. This is a creed of modernism; theories are becoming smarter and more progressive. The professional addiction curriculum would adhere to a steady improvement in theory and practice along the road to Damascus. However, Marx and Foucault disrupt this with several inversions.

Inversion 1: The Dialectical

Marx inverted the apparent Hegelian ideal of progress. Humanism was committed to an assumption to a transcendent idealism that defined the ways that human beings live, or should live. Hegel was positioned as very optimistic that this was occurring. Counsellors with their attraction to humanism were very much of this opinion, as newer practices and theories proceeded ineluctably in the right direction. However Marx inverted this theory in contending that the way we live defines our ideas. If we live in a situation of gross materialism and injustice that will define our thoughts and ideals, it was not so much a journey to Damascus but a progress to the shrine of Mammon. As counselling practices, proceeds their progress we not defined by therapeutic program but by simple economics.

Inversion 2

The psy sciences owe much to their assumptions to Freud's idea that individuals repress certain parts of their past, named by Foucault disparagingly as the repression hypothesise (Foucault, 1980). Allegedly this repression is exorcised by the secular confessional and the true subjectivity can be accessed. However Foucault saw subjectivity not so much as a released but a created identity in various discourses of entrapment. These nets are laid by unsuspecting counsellors on unsuspecting clients. Subjectivity is made available furnished by searing common sense sophistication.

\subsection{Deserting the Why for How-Motivational Interviewing}

Although the transition from the older practices to Motivational Interviewing look like a natural transition, in that MI commandeers many of the practices of older models especially the twelve steps, MI has been commandeered by the appeals of neo-liberalism. The use of MI also signals a watershed in the field. It resulted in a reconfiguration and distancing of the counsellor/client interaction. The counsellor is now more of a management consultant in the arts of self-care. 
Abandoned are the whys of aetiology in favour of the how's of management or self-management of subjectivity. The practice is not based on any aetiological theory (although it claims to be trans-theoretical). It is also intrinsically strength based as it works to occlude any lexicon around deficit. It also works to invert older terminology, i.e. the client is not seen to be intrinsically powerless but empowered. It is also vehemently non-judgemental.

One of the broader strategies includes the question by the counsellor.

Tell me, what some of the good things about drinking alcohol are.

This is followed by the question from the counsellor.

Tell me, what are some of the less good things about drinking alcohol?

The vitriolic euphemism less good obliterates any resistance by the client unless they of course they have a particular affinity with the use of sarcasm. Often in the power imbalance present in the clinician/client interaction this is impossible.

The therapeutic conversation proceeds in this way constructing a ledger balance sheet between good-less good. Any semblance of morality such as the word bad is explicitly obliterated from the vocabulary. However there is no doubt but that the undertone is left fairly and squarely from the panapticonal presence of the distant yet ever present professional clinician through the self-internalisation of a hyper rationalised morality.

At the end of the conversation the counsellor says:

One the one hand you like these things about alcohol-

Yet on the other, these are the less good things-

Followed by the key question:

Have I got that right?

There is no doubt that the practice is often effective. However, many clients who present are in a state of powerlessness and need more than this. In reality the practice is effective in the types of subjectivity that it creates in the first place.

It is also a practice originally developed for people who do not necessarily fit the DSMIV (American Psychiatric Association, 2000). criteria for dependency but maybe problematic use of drugs/alcohol Therefore the practice can be used on a much wider population under the ever hyper-inclusive remit of discourse of risk.

It could be argued that the client goes into the addiction counsellor with a presenting problem around drink driving, predisposing history to addiction, a perpetuating issue such as unemployment, but with a protective factor such as a supportive family. But after the interview they emerge as a remade and militantly balanced resilient positive individual. Proceeding with a spiritual tenor, the Spirit of MI comprises Collaboration, Evocation and Autonomy. (Miller \& Rollnick, 1991) encapsulating a neo-liberal spirituality describing a business client/clinician transaction conducted freely yet asymmetrically. Moreover as the state retracts counselling encourages both "institutions and individuals to conform to the norms of the market" (Larner, 2000: p. 11). Moreover moving forward the neo-liberal evangel is unremttingky positive and any hue of negativity rendered sacrilegious. Of course "there is nothing inherently negative or positive 
about reliance, as it is entirely contingent on who is wielding it, and for what political purposes" (Cretney cited in Deverteuill \& Golubchikov p. 144). On a macro level it does serve to synchronise the subjectivity of (teaching staff) or addiction specialist to the rationality of the business world.

\section{Possible Challenges}

Western culture and in particular counselling has existed in an occidental bubble safe from any real challenges apart from an appropriately funded and sanitised tokenism. The chronic use and abuse of verbal softeners, and euphemisms and indeed that word challenge has been softened down to of hyper-nothingness. But there are two main challenges.

\section{Local}

Stanley Cohen made a stunning yet undervalued assessment of the social aetiology of drug use, demand and supply when he wrote.

Society as presently structured will continue to generate problems for many of its members and will then condemn whatever solutions solution they choose (Jones 1997).

The Other

Many populations from a non-western viewpoint are also taking up the role of counselling as many move to the west. Many of these have an affinity to the reality of tragedy, dispossession and loss. They do not as yet, nor are unlikely to possess the wafer thin anaemic spirituality that stalks the middle-class west. There is a holiness that we all witness when we validate the great abyss.

\section{Conclusions}

The recent trajectory in the addiction counselling field has followed a teleology based on neo-liberal concerns rather than clinical considerations. Currently the conventional wisdom includes veneration towards the narratives of resilience and optimism. Addiction workers have learned to comply with this. The author argues that the journey out of addiction does not involve a banal customer/provider transaction but a dramatic tryptic including tragedy, farce and is lastly logic authorised not by market imperatives but by something bigger and smaller than all of us.

"Nietzsche believed that tragedy was born of the Greeks ability to keep their eyes fixed on the great darkness until they began to see flashes of light and insight" (Ruprecht, 2008: p. 106).

\section{References}

Alcoholics Anonymous (2001). Alcoholics Anonymous: The Story of How Many Thousands of Men and Women Have Recovered from Alcoholism. Center City, MN: Hazelden Publishing.

American Psychiatric Association (2000). Diagnostic Criteria from dsM-iV-tr. Arlington, VA: American Psychiatric Publishing.

Aquash, M. (2013). First Nations Control of Education: One Community's Experience. Canadian Journal of Native Education, 36, 59. 
Blake, W., \& Stevenson, W. H. (2007). Blake: The Complete Poems. London: Pearson Education.

Blockley, D. (2015). Finding Resilience through Practical Wisdom. Civil Engineering and Environmental Systems, 32, 18-30. https://doi.org/10.1080/10286608.2015.1022725

Bloom, H. (1970). Yeats (Vol. 378). New York, NY: Oxford University Press.

Bracke, S. (2016). Is the Subaltern Resilient? Notes on Agency and Neo-Liberal Subjects. Cultural Studies, 30, 839-855.

Carton, T. (2014). The Spirit of Motivational Interviewing as an Apparatus of Governmentality. An Analysis of Reading Materials Used in the Training of Substance Abuse Clinicians. Sociology Mind, 4, 192-205.

Clymer, L. (1995). Graved in Tropes: The Figural Logic of Epitaphs and Elegies in Blair, Gray, Cowper, and Wordsworth. ELH, 62, 347-386. https://doi.org/10.1353/elh.1995.0011

Davis, O. (2016). Resiling from "Resilience". Studies in Gender and Sexuality, 17, 135-138. https://doi.org/10.1080/15240657.2016.1172921

Dean, J. (2008). “The Lady Doth Protest Too Much": Theorising Disidentification in Contemporary Gender Politics. Ideology in Discourse Analysis, 24, 1-19.

DeVerteuil, G., \& Golubchikov, O. (2016). Can Resilience Be Redeemed? Resilience as a Metaphor for Change, Not against Change. City, 20, 143-151. https://doi.org/10.1080/13604813.2015.1125714

Ellis, A. (1992). Psychotherapy Can and Will Create Social Change. Hallelujah! Psychotherapy in Private Practice, 10, 117-121. https://doi.org/10.1300/J294v10n04_12

Fairclough, N. (1995). Critical Discourse Analysis. The Critical Study of Language. Abingdon-on-Thames: Routledge.

Foucault, M. (1980). The Eye of Power. In C. Gordon (Eds.), Power/Knowledge: Selected Interviews and Other Writings 1972-1977. New York, NY: Vintage.

Hutcheon, E., \& Lashewicz, B. (2014). Theorizing Resilience: Critiquing and Unbounding a Marginalizing Concept. Disability \& Society, 29, 1383-1397.

https://doi.org/10.1080/09687599.2014.934954

Jones, G. (1997). Youth Homelessness and the "Underclass". In R. MacDonald (Ed.), Youth, the 'Underclass' and Social Exclusion (pp. 96-112). London: Routledge.

Koestler, A. (1964). The Act of Creation. New York, NY: Macmillan Company.

Larner, W. (2000). Neo-Liberalism: Policy, Ideology, and Governmentality. Studies in Political Economy, 63, 5-25. https://doi.org/10.1080/19187033.2000.11675231

Miller, W. R., \& Rollnick, S. (1991). Preparing People to Change Addictive Behavior. London: Guildford Press.

Ruprecht, L. A. (2008). This Tragic Gospel: How John Corrupted the Heart of Christianity. Hoboken, NJ: John Wiley \& Sons.

Sacks, H., Schegloff, E. A., \& Jefferson, G. (1974). A Simplest Systematics for the Organization of Turn-Taking for Conversation. Language, 50, 696-735.

https://doi.org/10.1353/lan.1974.0010

Simard-Gagnon, L. (2016). Everyone Is Fed, Bathed, Asleep, and I Have Made It through Another Day: Problematizing Accommodation, Resilience, and Care in the Neo-Liberal Academy. The Canadian Geographer/Le Géographe Canadien, 60, 219-225. https://doi.org/10.1111/cag.12274

Sokolon, M. K. (2013). The Shameless Truth: Shame and Friendship in Aristotle. European Journal of Political Theory, 12, 447-465. 
https://doi.org/10.1177/1474885112471273

Thornborrow, J. (2002). Power Talk. London: Language and Interaction in Institutional Discourse.

Wright, A. (2012). Fantasies of Empowerment: Mapping Neo-Liberal Discourse in the Coalition Government's Schools Policy. Journal of Education Policy, 27, 279-294. https://doi.org/10.1080/02680939.2011.607516

Zizek, S. (2011). The Truth Shall Set You Free, But Not This Truth. ABC Religion \& Ethics (Opinion).

Submit or recommend next manuscript to SCIRP and we will provide best service for you:

Accepting pre-submission inquiries through Email, Facebook, LinkedIn, Twitter, etc. A wide selection of journals (inclusive of 9 subjects, more than 200 journals)

Providing 24-hour high-quality service

User-friendly online submission system

Fair and swift peer-review system

Efficient typesetting and proofreading procedure

Display of the result of downloads and visits, as well as the number of cited articles

Maximum dissemination of your research work

Submit your manuscript at: http://papersubmission.scirp.org/

Or contact aasoci@scirp.org 